\title{
HYGIENIC SIGNS OF DIAGNOSTICS OF EARLY DYSMETABOLIC DISORDERS SYMPTOMS
}

DOI: 10.36740/WLek202002118

\author{
Nataliya M. Poberezhna, Serhii T. Omelchuk, Serhii A. Pavlovskyi, Maryna 0. Pavlovska \\ BOGOMOLETS NATIONAL MEDICAL UNIVERSITY, KYIV, UKRAINE
}

\begin{abstract}
The aim of the study was to identify certain health features among healthy people that can serve as a risk factor and lead to the further development of metabolic syndrome. Materials and methods: A total of 79 men, completely health, were interviewed during 2019 at the Center for Health and Longevity Technology (Kyiv) to assess their health and further correction recommendations for identified abnormalities and available changes. The mean age of men was (37.18 \pm 0.89$)$ years. Non-invasive methods were used in the study: determination of anthropometric parameters - height, body weight, waist circumference, abdomen, index of ratio of waist-to-waist circumference, body mass index, body shape index. The constituent compositions of the body were performed with an InBody 220 apparatus with impedance analysis. The metabolic profile was evaluated using FITMATE, a portable metabological device. The cardiovascular profile was determined in the CARDIOLAB + HRV system. The obtained digital data were processed by the method of variational statistics using Microsoft Excel 7.0.

Results: It was found that in 44 (54.4\%) of the surveyed men, the waist circumference exceeded $94 \mathrm{~cm}$. The largest number of such persons was found among men aged $31-40$ years - ( $29.11 \%$ of the surveyed in this group) and persons aged $41-50$ years $-21.52 \%$. Fat distribution (waist circumference / hip circumference) averaged (0.83 \pm 0.02$)$. The difference in the body shape index between the group of young persons and groups of older men was established. The predisposition to metabolic disorders is established in $49,37 \%$ of cases. Determination of metabolic profile revealed a deviation toward an increase in actual metabolism in 15 people and 15 - in the direction of reducing it.

Conclusions: Thus, the results of a thorough examination of healthy men showed that they may have health changes that characterize the early signs of disease risk, and their presence can be detected by simple non-invasive research methods. The doctor's task is to assign an in-depth study of the risk factors for the development of a particularly common in our time prevalence of a complex multicomponent metabolic syndrome, which includes the symptoms of the defeat of many body systems, in particular, the endocrine, cardiovascular, urinary and other in order to preserve human health and to recognize it as early as possible, prevent it and avoid complications.
\end{abstract}

KEY WORDS: obesity, metabolic syndrome, developmental risks

Wiad Lek. 2020;73(2):302-305

\section{INTRODUCTION}

According to the latest data, more than $10 \%$ of adults suffer from obesity [1]. Obesity is a risk factor for diabetes, cardiovascular disease, metabolic syndrome and others $[2$, $3]$. At the same time, the issue of epidemiology and the significant spread of metabolic syndrome in a population of people of all ages is of concern [1, 4-6, 7].

Cardiovascular diseases are closely linked to the dysmetabolic disorders that are accompanied by obesity. Individuals over 40 years of age use a special Score for Systematic Coronary Risk Evaluation (SCORE) to determine the risk of developing cardiovascular disease risk over the next 10 years, including gender, age, and smoking, total cholesterol and other factors [8]. According to the Fremingham study, for every $4.5 \mathrm{~kg}$ of body weight, systolic blood pressure increases by $4.4 \mathrm{~mm} \mathrm{Hg}$ among men and $4.2 \mathrm{~mm} \mathrm{Hg}-$ among women [2]. Therefore, the problem of a thorough examination of the person arises before the emergence of classic dysmetabolic manifestations, which may develop later into the metabolic syndrome. According to the International Diabetes Federation, insufficient attention is paid to human anthropometric status data, including the inclusion of body composition, metabolic and cardiovas- cular profiles with the likely need for in-depth study of lipidemic and glycemic profiles.

\section{THE AIM}

The aim of the research was to identify certain health features among healthy people that can serve as a risk factor and lead to the further development of metabolic syndrome.

\section{MATERIALS AND METHODS}

In total 79 completely health men were examined during 2019 at the Center for Health and Longevity Technology (Kyiv) to assess their health and further correction recommendations for identified abnormalities and changes. The mean age of men was $(37.18 \pm 0.89)$ years. There were 13 persons in the first age group (21-30 years), in the second age group (31-40 years) - 38 persons, $41-50$ years -23 persons and $50-60$ years -4 persons.

Non-invasive methods were used in the study: determination of anthropometric parameters - body height, body weight, waist circumference, abdomen circumference, 
index of waist-to-hip ratio, body mass index, body shape index and body weight index. Body height and body weight was measured by InBody BSM 370 (South Korea).

The constituent compositions of the body were measured by an InBody 220 apparatus with mode of action based on on multifrequency bioelectric impedance analysis. The computer algorithm of interpretation of the results of the research allows to reliably estimating the objective state of the organism of the subject online. With the help of the analyzer, the following results can be obtained: determination of body mass index, percentage of adipose tissue; waist-to-hip ratio, charting with age; segmental evaluation of the muscular and skeletal mass of the organism.

The metabolic profile was evaluated using FITMATE, a portable metabolograph. COSMED is the first portable device designed for accurate measurement of basal metabolism value (Resting Energy Expenditure (REE, RMR)), for correcting excess body weight, obesity, or malnutrition. Fitmate $\mathrm{s}$ is a unique desktop system for accurate, fast and easy indirect calorimetry; accurate measurement of the basic metabolic rate; affordable, portable, easy to use, has a built-in thermal printer; body weight management programs based on energy balance; includes software for data management, lifestyle analysis and diet planning.

The cardiovascular profile was determined with CARDIOLAB + HRV system, which is an electrocardiograph with analysis of heart rate variability and the presence of ECG-monitoring mode with detailed analysis of heart rate variability. The system has a complete set of functions of a CARDIOLAB cardiograph and records with a detailed analysis of heart rate variability characteristics by the European Working Group technologies and in accordance with the R.M. Baevsky analysis recommendations.

The obtained digital data were processed by the method of variation statistics using Microsoft Excel 7.0 application program.

\section{RESULTS AND DISCUSSION}

It is known that the volume of visceral adipose tissue plays an important role in the development of metabolic syndrome and, accordingly, is interpreted as a predictor of its development, which significantly complements the body mass index. In general, the volume of visceral (abdominal) fat is determined accurately using magnetic resonance imaging. In the real world - taking into account accessibility, security, cost and other factors. Since this is not available, doctors are focusing on the waist circumference and waist / hip ratio.

Waist circumference is now considered as the indicator of central obesity. In 44 surveyed men, this indicator exceeded the norm $(94 \mathrm{~cm})$. The highest number was found among men aged $31-40$ years - $(29.11 \%$ of the surveyed in this group). A large number was also found among men aged $41-50$ years $-21.52 \%$. Accordingly, the index of abdomen circumference also increases. Fat distribution (waist circumference / hip circumference) averaged $0.83 \pm$ 0.02 ( 0.85 for men). In the age group of $21-30$ years $1.54 \%$ persons were with the higher index, in the group of 31-40 years $-49.5 \%$, in the group of $41-50$ years $-72.91 \%$, in the group of $51-60$ years $-100 \%$.

The body mass index (Kettle) among the surveyed men varied significantly in different groups. In the age group of 21-30 years 4 people (30.66\%) had normal weight, 9 people $(69.23 \%)$ were overweight. In the group of 31-40 years 3 people $(7.9 \%)$ had normal body weight, overweight -21 people $(55.26 \%)$, I degree obesity - 11 people $(28.95 \%)$, II degree obesity - 2 people (5.26\%), III degree obesity - one person $(2.63 \%)$. In the $40-50$ age group, persons with normal body weight were $4.35 \%$ ( 1 case), excess $-52.17 \%$ ( 12 cases), I degree obesity $-21.74 \%$ ( 5 cases), II degree obesity -- 21.74\% (5 cases), III degree obesity - were not observed. Among persons over 50 years of age, persons with normal body weight were not detected, with overweight -2 people (40.0\%), with I stage obesity -- 2 people (40.0\%). Therefore, with age the number of men with obesity increases, instead the number of men with normal and excess body weight (overweight) decreases.

Increasing body mass index may be related to other indicators of body composition - bone volume and skeletal muscle. A study of bone volume revealed that this indicator fluctuated in different age groups. In the age group of 21-30 years, the average bone volume was $5.15 \pm 0.67 \%$ (4.09; $7.08)$; in the $31-40$ age group $-4.99 \pm 0.81 \%(4.05 ; 6.67)$, in the $41-50$ age group $-4.12 \pm 1.24 \%(4.34 ; 6,36)$, in the group of $51-60$ years $-4,50 \pm 1,17 \%(4,03 ; 5,41)$. The index did not differ significantly between the different age groups ( $\mathrm{p}>0.05)$.

The volume of skeletal muscle mass in the age group of $21-30$ years - $(45,40 \pm 0,89 \%(32,1 ; 58,70)$; in the group of $31-40$ years $-41,60 \pm 0,92 \%(16,60 ; 60,05)$, in the group of $41-50$ years $-30,42 \pm 0,73 \%(28,8 ; 48,9)$, in the group of $51-60$ years $-38,30 \pm 1,02 \%(34,0 ; 45,5)$. That means, that the volume of skeletal muscle mass decreases with age.

Fat volume also has differences, depending on the age of the person. Thus, at the age of 21-30 years this index is the lowest $-15.50 \pm 0.53 \%(6.3 ; 2.88)$. In the $31-40$ age group -index significantly increases to $31.10 \pm 1.02 \%$ $(10.5 ; 39.8)$ and remains within that range in the $41-50$ age group $-30,8 \pm 1.07 \%(11.7 ; 45.0)$ and $29.2 \pm 0.71 \%$ in the age group over 50 years. At the same time, fat mass percent also increased: at the age of 21-30 years index was $16,55 \pm 0,38 \%$; at the age of $31-40$ years $-22,9 \pm 0,45 \%$; 41-50 years $-27,4 \pm 0,56 \%$ and over 50 years $-28,6 \pm$ $0,91 \%$. Among the surveyed men, 42 (53.16\% of cases) showed excessive development of subcutaneous adipose tissue, mainly in the upper half of the body.

According to the World Health Organization, obesity is becoming a "real epidemic" of the 21st century. Approximately $10 \%$ of adults suffer from obesity [1], in $40 \%$ of cases comorbid with diabetes mellitus and $20 \%$ with coronary heart disease. With obesity the risk of cardiovascular disease, diabetes increases, which are important criteria for metabolic syndrome. 39 people out of 79 surveyed (49.37\%) had a predisposition to metabolic disorders. Determination of metabolic profile revealed a deviation 
toward an increase in actual metabolism in 15 people and 15 - in the direction of reducing it.

The body shape index, closely linked to abdominal obesity, is a new indicator of the risk of premature death from cardiovascular disease [9]. It is now suggested that there is a relationship between body shape index and diabetes mellitus, metabolic syndrome, and hypertension [10-13]. In our research, among the surveyed persons in groups of persons of different ages, this figure was in persons aged 21 - 30 years $-0.38 \pm 0.18$; $31-40$ years $-0.34 \pm 0.17$; 41 50 years $-0.35 \pm 0.18$; more than 50 years $-0.34 \pm 0,16$. Therefore, there is a difference in the value of the indicator between a group of young people and groups of older men. Perhaps the body shape index is one of the first to respond to changes in metabolic status.

When measuring blood pressure, the vast majority of men in all groups set values within the normal range. Nine people ( $11.39 \%$ of cases) had blood pressure higher than $130 / 90 \mathrm{~mm} \mathrm{Hg}$. At the same time, their waist circumference exceeded $102 \mathrm{~cm}$. Among the same persons according to the body mass index overweight revealed in one case, I degree obesity - five people, II degree obesity - one person.

Thus, the results of a thorough examination of healthy men showed that they might have health changes that characterize the early signs of disease risk, and their presence can be detected by simple non-invasive research methods. The doctor's task is to assign a deep examination of the risk factors for the development of a particularly common in our time prevalence of a complex multicomponent metabolic syndrome, which includes the symptoms of the defeat of many body systems, in particular, the endocrine, cardiovascular, urinary and other in order to preserve human health and to recognize it as early as possible, prevent it and avoid complications [14]. N. Wangea [15] reported an average age of diagnosis of metabolic syndrome of 49.5 years, whereas our study found signs of risk factors for the disease in young people - 31-40 years, which needs attention for men of this age category - appointment detection of additional parameters, as recommended by the International Diabetes Federation.

\section{CONCLUSIONS}

1. $44(54.4 \%)$ surveyed men had waist circumference that exceeded $94 \mathrm{~cm}$. The largest number of such persons was found among men aged $31-40$ years $(29.11 \%$ of the surveyed in this group) and persons aged 41-50 years $-21,52 \%$. Fat distribution (waist circumference / hip circumference) averaged $0.83 \pm 0.02$. With age, the number of men with excess rates is increasing.

2. According to the body mass index it is established that with age the number of men with obesity of varying degrees of severity increases, but instead decreases with normal and excess body weight (overweight).

3. Changes in indicators of body composition occur with age: bone volume between different age groups is not significantly different ( $p>0.05)$; the volume of skeletal muscle decreases; the volume and percentage of fat at the age of $21-30$ years is the lowest $-15.50 \pm 0.53 \%$, and after
30 years it grows and remains so until 60 years, which should be taken into account when analyzing the value of the body mass index.

4. There is a difference in the value of the body shape index between a group of young people and groups of older men. Perhaps the body shape index is one of the first to respond to changes in metabolic status. 39 people out of 79 examined (49.37\%) had a predisposition to metabolic disorders. Determination of metabolic profile revealed a deviation toward an increase in actual metabolism in 15 people and 15 - in the direction of reducing it.

5 . Nine people (11.39\% of cases) had blood pressure higher than 130/90 mm Hg. Art. At the same time waist circumference in them exceeded $102 \mathrm{~cm}$. Among the same persons according to the body mass index overweight revealed in one case, obesity of the first degree -five people, obesity of the second degree - one person.

\section{REFERENCES}

1. World Health Organization newsletter. 2014: 311.

2. Akhmetov A.S. Ozhy rinnya - epidemiya 21 storichya [0besity is an epidemic of the 21st century]. Ter. arkhiv. 2002; 10:5-7. (In Ukrainian).

3. Kovalenko V.N. Paciyent z vysokym sercevo-sudynnym ryzykom: chy mozhna zbilshyty tryvalist zhyttya. [Patient at high cardiovascular risk: can life expectancy be increased]. Zdorovia Ukrainy. 2007; 21(1):10-11. (In Ukrainian).

4. Donirova 0. Rasprostranennost komponentov metabolicheskogo sindroma sredi pozhilykh patsientov [Prevalence of components of metabolic syndrome among elderly patients]. Vesti buryat un-ta. 2009; 12:111-114. (In Russian).

5. Zhuravlev Yu.I., Tkhorikova V.N. Evolyuciya uyavlen pro kryteriyi diagnostyky ta epidemiologiyi metabolichnogo syndromu (oglyad literatury) [The evolution of ideas about the criteria for the diagnosis and epidemiology of metabolic syndrome (literature review)]. Profilakt med. 2014; 17(4):52-56. (In Ukrainian).

6. Zavyalova L.G. Rasprostranennost insulinorezistentnosti i ee svyaz s komponentami metabolicheskogo sindroma u podrostkov (po dannym populyatsionnogo issledovaniya) [Prevalence of insulin resistance and its association with components of metabolic syndrome in adolescents (according to a population study)]. Ros. kardiol. zhurn. 2012; 4:37-42. (In Russian).

7. Mitrofanov I.M. Poshyrenist metabolichnogo syndromu v organizovanij populyaciyi [Prevalence of metabolic syndrome in an organized population]. Klin. med. 2012; 90 (11):47-50. (In Ukrainian).

8. Mikropulo I.R., Maslennikova N.0., Prikhodko V.M. Profilaktika serdechno-sosudistykh riskov: podozhdat do soroka let [Cardiovascular risk prevention: should you wait up to forty years]. MP. 2011;3(79):117122. (In Russian).

9. Oslopov V.N., Bogoyavlenskaya 0.V. Indeks formy tela - novyy pokazatel riska prezhdevremennoy smerti [Body shape index is a new indicator of risk of premature death]. Kazan med zh. 2015;96(2):253-256. (In Russian).

10. Cheng JB. A body shape index in middle-aged and older Indonesian population: scaling exponents and association with incident hypertension. PLoS One. 2014;9(1):e85421.

11. Duncan MG, Mota G, Vale S. Assotiations between body mass index, waist circumference and body shape index with resting blood pressure in Portuguence adolescents. Ann Hum Biol. 2013;40:163-7. 
12. He $S$, Chen X. Could the new body shape index predict the new onset of diabetes mellitus in the Chines population. PLoS One. 2013;8(1):50573.

13. Matsha TE, Hassan VS, Hon GM. Derivation and Validation of a waist circumference optimal out off for diagnosting metabolic syndrome in a South Africa mixed ancestry population. Intern J Cardiol. 2013;168:2954-5.

14. Tkachenko VI, Bagro TO, Vydyborecz NV, Bondar OK. Metabolichnyj syndrom: diagnostyka ta profilaktyka v praktyci simejnogo likarya. [Metabolic syndrome: diagnosis and prevention in the practice of the family doctor]. Liky Ukrayiny. 2016;1-2:197-198. (In Ukrainian).

15. Wang H, Liu A, Zhao T. Comprasion of anthropometric indices for predicting the risk of metabolic syndrome and components in Chinese adults: a prospective longitudinal study. BMJ Open. 2017;17(9): e016062.

\section{ORCID and contributionship:}

Nataliya M. Poberezhna - 0000-0003-4026-4468 A, D, F

Serhii T. Omelchuk - 0000-0003-3678-4241 ${ }^{\mathrm{E}}$

Serhii A. Pavlovskyi -0000-0002-4087-6256 ${ }^{B}$

Maryna O. Pavlovska -0000-0001-9213-1072 ${ }^{\mathrm{C}}$

\section{Conflicts of interest:}

Authors declare no conflict of interest.

\section{CORRESPONDING AUTHOR}

\section{Serhii T. Omelchuk}

Bogomolets National Medical University

T. Shevchenko boulevard, 13, 01601, Kyiv, Ukraine

tel: +380679009013

e-mail:md.omelchuk@ukr.net

Received: 08.010.2019

Accepted: 19.01.2020

A - Work concept and design, B - Data collection and analysis, C - Responsibility for statistical analysis,

D - Writing the article, $\mathbf{E}$ - Critical review, $\mathbf{F}$ - Final approval of the article 